Int. J. Speleol., 26, 3-4 (1997): 29 - 48

\title{
MARTEL'S LINKS WITH USA
}

\author{
Trevor R. Shaw*
}

\begin{abstract}
Of the $29 \%$ foreign members in the Société de Spéléologie, five lived in USA. They were Luella Owen (the only woman member of the Société), R. Ellsworth Call, H.C. Hovey, P. Van Epps and C. R. Blackall. E.S. Balch, though not a member, also knew Martel. These members, between them, published ten papers in Spelunca, which also reviewed their other work. The activities of these six, and their links with France, are discussed. Martel actively encouraged cave work in America, as elsewhere, and Hovey, who had been with him during the survey of Aven Armand, he knew quite well. In 1912 Martel at last visited USA himself and the barometer readings he took in Mamoth Cave to measure altitude enabled him to draw the first longitudinal section of the cave since 1835 .
\end{abstract}

Martel was more than just a cave explorer, cave researcher and writer. He also consciously caused the study of caves to spread into countries outside the European core where it was already flourishing. He was a leader who inspired and encouraged people to investigate the caves and karst problems of their own lands.

There can be no doubt about the extent of Martel's personal links with speleology in other countries. Of his 26 annual campaigns of exploration, 19 went outside France in what are now 20 nations and in addition he made lecture tours and other visits abroad. At least 61 of his own publications on caves appeared elsewhere in his lifetime. Many of these were papers presented to learned societies, and there were also popular articles and the texts of public lectures; others were simply translations or reprints of work already published in France, showing the interest with which this was regarded abroad.

The Société de Spéléologie, which Martel founded in Paris in 1895, enjoyed high scientific standing from the outset and it was one of the means by which he contrived the extension of cave study into an international subject. Foreign membership of the Société was remarkably high. $21 \%$ of the founder members lived outside France, indicating the close links already existing before 1895. Between 1895 and 1904 the proportion rose to $29 \%$; in addition three foreign cave societies were members. Many papers by foreign contributors, most of them members, were published in the Société s journal, Spelunca, comprising between $14 \%$ and $50 \%$ of the papers printed in individual years. An investigation of these aspects, with numerical analyses of foreign membership and publication and their relationship to Martel's own travels,

(*)Karst Research Institute, Titov trg 2, SI 6230 Postojna, Slovenia. 
was presented at an earlier Martel centenary meeting'.

It was not only in karstologically developing countries that his influence was felt. Mais $^{2}$ has demonstrated the close collaboration that existed between Martel and Franz Kraus together with the well-established cave groups of Austria and the classical Karst of present - day Slovenia.

The purpose of this paper is to examine Martel's relationship with the United States of America. Because of the distance between that country and France, he did not go there until 1912 - more than 20 years after his earliest exploration campaigns in Belgium and Greece. So his influence and the links he created between explorers and researchers in the two countries necessarily followed a different pattern. Influence he certainly had, and contacts with fellow-workers were established, but in most cases these arose from his published writings and no doubt also from personal letters most of which are still untraced. His standing in the Société de Géographie, of which he was ultimately President, helped especially in his dealings with the American Geographical Society.

Most of the present study will discuss his relations with four individual Americans who became members of the Société de Spéléologie (and one who did not); and his 1912 visit to USA, with his researches there in Mammoth Cave, will also be described. First, though, are considered the several means by which Martel set about bringing together the cave workers of both continents.

\section{BRINGING FRANCE AND USA TOGETHER}

The ways in which Martel strove to promote the study of caves in USA, as in other countries outside France, may conveniently be considered under six headings:

a) publishing information in Europe about US caves;

b) making people in USA aware of cave work elsewhere, by publication in America;

c) direct encouragement by lectures or personal contact;

d) attracting Americans to become members of the Société de Spéléologie and by exchange of its publication, Spelunca, with those of scientific bodies in USA;

e) printing papers written by Americans in Spelunca;

f) visiting USA and carrying out his own researches there.

All these activities were concurrent with similar efforts with other countries and took place only in the time left available while he was carrying out his own exploration programme elsewhere, writing innumerable books and research papers, and working as a respected lawyer in Paris. The way in which he exerted his influence in USA was somewhat unusual, as already mentioned, because most of his links with that country were forged before he himself had made his first visit there.

As early as 1894 he included descriptions of several of the major American caves in his book Les Abîmes ${ }^{3}$, acknowledging among the sources of his information writings by Hovey and reports of state geological surveys, as well as Austrian, German and French publications. Information about Marble [now Marvel] Cave in Missouri was included in Spelunca in $1897^{4}$. Then in 1904 Max Le Couppey de la Forest ${ }^{5}$ published in Spelunca an account of his 1903 visits to Mammoth Cave and Colossal Cave 
in Kentucky, Wyandotte Cave in Indiana, and Wind Cave and Grand Cavern in Colorado. The Kentucky cave plans in this paper were previously unpublished and that of Wyandotte Cave was the first to be printed with a reasonably accurate scale ${ }^{6}$. In 1906 Martel occupied 18 pages in Spelunca ${ }^{7}$ with 81 notes and abstracts of reports on US karst subjects; and in 1910 he produced a lengthy review ${ }^{8}$ of the US Geological Survey Water Supply ... Papers relating to underground water.

Martel's two-part paper on the French region of the Causses and its caves was translated into English and published in America in 1893\%. In 1906 a review of his cave exploits appeared in a popular American magazine ${ }^{9 \mathrm{~A}}$, and a lecture by him had been read, in his absence, at the 8th International Geographic Congress at Washington DC in $1904^{10}$. Besides explaining what speleology is, as a branch of physical georgraphy with "a kind of individuality as a science of itself", and reviewing some of the recent cave investigations in Europe, he encouraged similar work in USA:

My aim in this little paper will be to suggest how useful and interesting would be a serious exploration of American caverns from the numerous and very different points of view which, during twenty years only, have been so successfully disclosed in the European underground inquiries - especially since new caves are yearly discovered in America...

I earnestly wish and advise that the geographical and geological societies or tourists` clubs in America may make their best efforts to have their gigantic caves carefully preserved by cave hunters in the way actually practiced in Europe by the specialists who claim the name of speleologists.

He continued, "I will note a few of the problems yet to be resolved in American caves" and listed eight such problems in an attempt to provoke action.

The Société de Spéléologie was formed in France in 1895 and it has already been seen that a high proportion of its members lived elsewhere. In 1896 there appeared in the American periodical Applachia" a review of the first issue of Spelunca, together with the statement that "its regulations admit of members in any part of the world, and it will be glad to welcome to its ranks all who are interested in its especial subjects."

American members joined in the following years:

1895 Miss Luella Agnes Owen : St. Joseph, Missouri

1896 Dr Richard Ellsworth Call : Brooklyn, New York

1897 Dr Horace C. Hovey : Newburyport, Massachusetts

1898 Percy Van Epps : Glenville, New York state

1900 Dr Christopher Rubey Blackall : Philadelphia

With the exception of Blackall, all these members had more or less active links with the Société and are discussed later. Blackall himself, head of the editorial department of the American Baptist Publication Society, is known for the plan of Mammoth Cave which he made in 1870 and 1871 but which was suppressed by the cave management because it showed that the passages ran beneath other property ${ }^{12,13}$. 
By September 19n4, publication exchanges had been arranged between the Société and the American Geographical Society and the US Geological Survey ${ }^{14}$; by October 1909 the Smithsonian Institution and the National Geographic Society had been added to the exchange list ${ }^{15}$. Such societies also published reviews of Martel's books ${ }^{15 \mathrm{~A}}$.

Papers written by American members and printed in Spelunca are noted in subsequent sections. The authors benefited from the fact that Spelunca had a world-wide readership and thus was the first international publication to cover the separate discipline of speleology.

\section{E. S. BALCH}

Edwin Swift Balch (1856 - 15 March 1927) ${ }^{16}$ was apparently never a member of the Société; certainly he was not included in the membership lists of $1895^{17}, 1904^{18}$ or $1909^{19}$, nor did he publish in Spelunca. But his important book and his papers on ice caves or glacières were reviewed there at length and Martel provided a significant amount of the information he used.

Balch was a competent mountaineer, a painter who exhibited regularly in Philadelphia, something of an ethnologist, and an early advocate of the submarine. As a child he lived in Europe with his parents and went to school in France and Germany before graduating at Harvard University ${ }^{20,21}$. Many of his publications were on the formation of ice underground and culminated in his book of 1900.

Glacières or Freezing Caverns ${ }^{22}$, a book of 337 pages, contains descriptions of all ice caves known to the author world-wide as a result of his own travels and an extensive literature search, together with reprints and discussion of many of the early theories seeking to explain how the ice was formed and how it remained throughout the year. The book is still regarded as a standard reference work on glacières ${ }^{23}$. The only known letter from Balch to Martel $^{24}$ refers to some visits that Balch had just made to glacières in the Alps; but there was probably some other communication between them. Balch includes Martel's name in his list of acknowledgements ${ }^{25}$, and in the tex ${ }^{26}$ he specifically credits him with published information about 17 caves.

Martel wrote a very favourable review of the book in Spelunca ${ }^{27}$ :

M. Balch nous donne ici un traité définitif des glacières naturelles :

lauteur a inspecté lui-même les principales glacières de France, d`Europe et d'Amérique; très justement il adopte pour l'origine des glacières le froid de l'hiver, la forme de la cavité, sa situation topographique et l'évaporation. M. Balch complète et met au point (jusqu'à fin 1899) avec une sérieuse critique personnelle at avec l'expérience des choses vues, les ouvrages antérieurs de Browne, De Luc, Fugger, Lohmann, Schwalbe, Thury, etc. Comme il réfute victorieusement les anciennes théories (fausses ou trop compliquées) de la glace des périodes glacières, de la chaleur estivale, des sels chimiques, des ondes alternées de chaud et de froid, de la capillarité ou air comprimé il faut considérer son excellent livre comme ayant épuisé la matière, sauf découvertes nouvelles et imprévues.

He had already, a few years earlier, made a detailed assessment ${ }^{28}$ of two previous papers by Balch on the causes of subterranean ice. 


\section{MISS L. A. OWEN}

Luella Agnes Owen (1852 - 31 May 1932) (Fig. 1) explored a number of quite difficult caves in the Ozarks and Black Hills regions of southern Missouri and South Dakota, notably Marble [now Marvel] and Wind Cave. She did this from 1893 onwards and her published descriptions did much to make American caves known in Europe. She made no original discoveries herself and the detailed survey she published of Marvel Cave had been made by a local naturalist, S. Fred Prince. Indeed the purpose of her book of $1898^{29}$ was as much to put forward her ideas on speleogenesis in that region as to describe the caves themselves. Miss Owen`s cave work had started as early as 1873 or very soon afterwards, when she did field work with Hovey $^{30}$. She later sent him an autographed copy of her book ${ }^{31}$.

She was the first of the American speleologists to join the Société de Spéléologie, which she did in 1895 (after May 1), the same year in which she became a Fellow of the American Geographical Society ${ }^{32}$. The last of the published membership lists, for October 190919, records that she was still a member then, and still the only woman member of the Société. Already in 1895 she had presented to its library a copy of the very scarce 1854-55 Report of the Geological Survey in Kentucky ${ }^{33}$.

Four separate papers written by her on American caves were published in Spelunca between 1896 and $1899^{34-37}$, and there was also her summary of her own book printed together with reproductions of two of the cave surveys ${ }^{38}$. The four papers were all original, not adapted from work already published in USA, as happened with Call and Hovey.

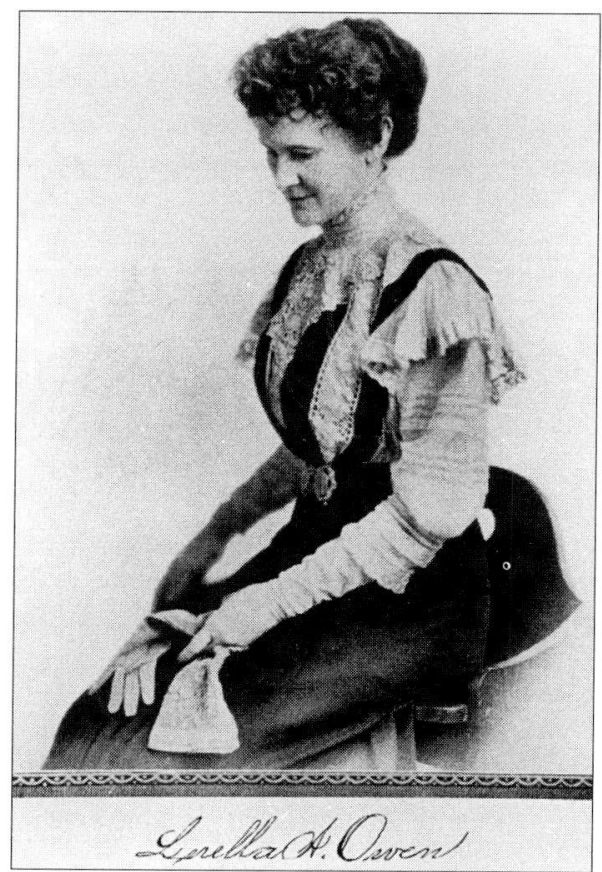

Fig. 1. Luella Agnes Owen. Reproduced from F.C. Shoemaker : Missouri and Missourians. Vol. 4.

Chicago, Lewis Publishing Co., 1943, by permission of The State Historical Society of Missouri 


\section{R. ELLSWORTH CALL}

Dr. Richard Ellsworth Call (13 May 1856 - 14 March 1917) (Fig. 2) was a school teacher, geological surveyor and professor of zoology ${ }^{39,40}$. He wrote guidebooks on Mammoth Cave and is perhaps best known as Hovey`s collaborator in The Mammoth Cave of Kentucky, first published in $1897^{41}$. He became a member of the Société de Spéléologie in 1896 and was still listed as one in September $1904^{18}$ but not in October $1909^{19}$. His paper on the history of the various plans made of Mammoth Cave (a shortened version of a paper already published in English in Indiana ${ }^{42}$ ) was included in Spelunca in $1897^{43}$, and in the same year reviews appeared there ${ }^{44,45}$ of the Hovey/Call book and also of a paper he had written on the flora of Mammoth Cave. The 1914 bibliography of Mammoth Cave, which he compiled together with Hovey, is referred to later.

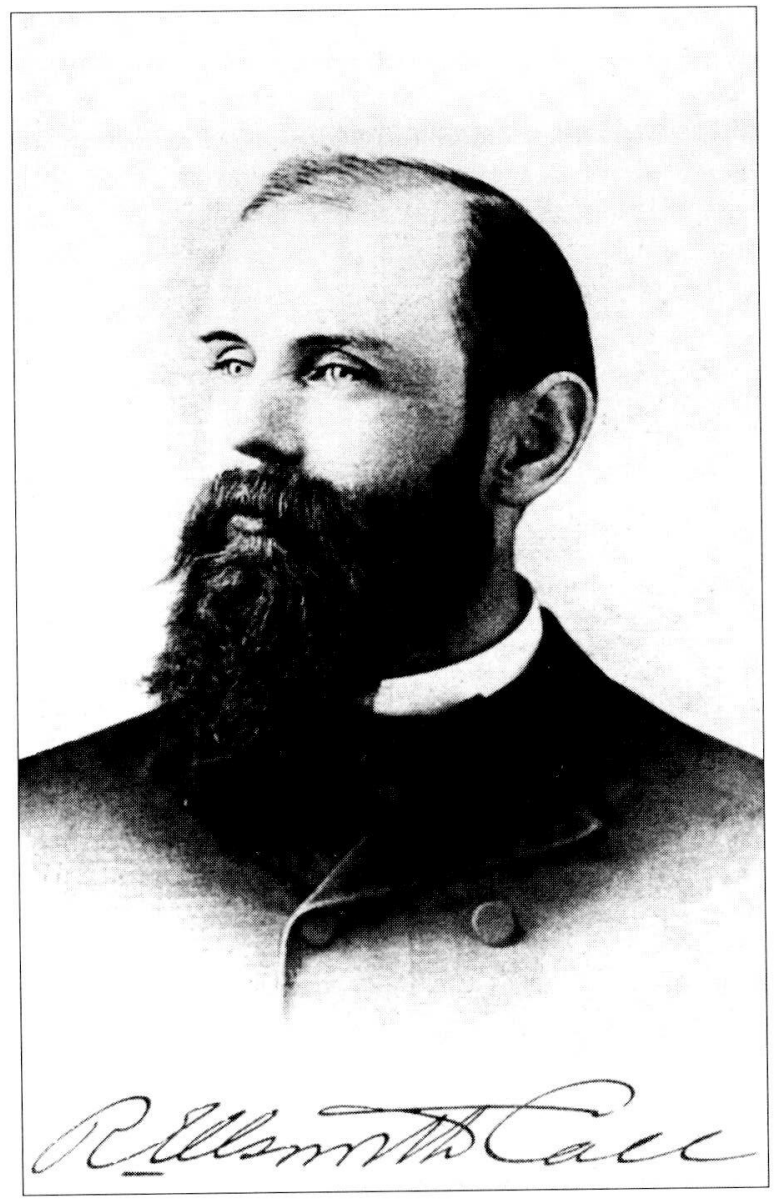

Fig. 2. Richard Ellsworth Call ${ }^{40}$. 


\section{H. C. HOVEY}

Dr. Horace Carter Hovey (28 January 1833 - 27 July 1914) (Fig. 3) is probably the most important American in the context of this paper, for he knew Martel personally, was present with him at the exploration of the Aven Armand in 1897, gave Martel an inscribed copy of his own book, and published a review of one of Martel`s books, besides being a member of the Société and a prolific author in Spelunca.

Hovey was a Presbyterian priest and his doctorate was in divinity. His cave knowledge was mostly gained from tourist caves ${ }^{46,47}$ but his numerous writings and lectures $^{48}$ served to make the American public aware of them. His classic book, Celebrated American Caverns ${ }^{49}$, appeared in 1882 . His importance was mainly as a populariser, but he came at a time when there was little other material available on American caves. He took his caves seriously and was regarded as an authority on the subject,

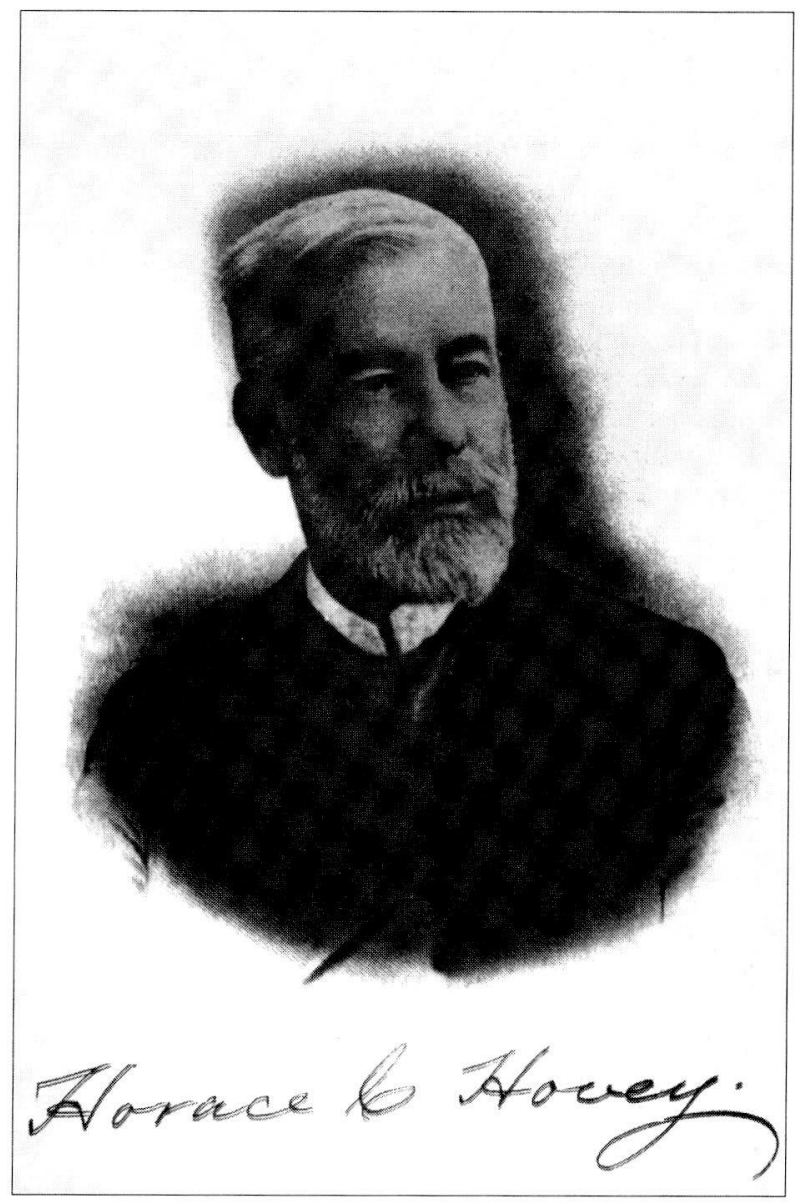

Fig. 3. H.C. Hovey at the age of 64. From a picture taken in 1897 by a photographer named Thompson and published as an engraving by E.G. Williams and Brother of New York. 
for he wrote many of the cave entries for Encyclopaedia Britannica.

Although there is an archive of Hovey papers in Crawfordsville, Indiana ${ }^{50}$, there are gaps in it and there is reason to think that other papers may exist that are still inaccessible ${ }^{50,51}$.

How Martel and Hovey first got acquainted is not at present known. It was in 1897 that Hovey became a member of the Société, and it was in September of that year that he took part, with Martel, in the exploration of the Aven Armand, but which came first is unknown; in either case he must have been in touch with Martel beforehand. In view of Hovey's eminence as a writer and the fact that his well-known book had appeared in 1882, Martel may have known him for a long time. Certainly Hovey`s book is cited in Les Abîmes as early as $189^{43}$, and in 1897 Martel remarked of Hovey, "peut être appelé le précurseur de la spéléologie en Amerique"s2.

Martel mentions ${ }^{52}$ that Hovey "a pris part, en septembre 1897, à l’excursion générale de la Société dans les Causses". He was in France en route back from the International Geological Congress held in St. Petersburg from 29 August to 5 September. Before that he had been on a Congress excursion to the Urals together with his son E.O. Hovey of the American Museum of Natural History ${ }^{52 \mathrm{~A}}$. Hovey himself described the Aven Armand exploration in some detail. "From his interest in the study of caves Dr. Hovey was led to join an expedition under the leadership of M. Edouard A. Martel." "53 "Only four of our party undertook this somewhat perilous exploration, namely, Messrs. Martel, Viré, Armand and myself." ${ }^{44}$

Martel's statements are more precise. He records that, the entrance having been found by Louis Armand on 17 September, the cave was explored from 19 to 21 September. On 19 September only Viré and Armand accompanied him. "Les deux seuls membres qui subsistent de la caravane spéléologique, M. Hovey et M. Desse, demeurent au Rozier pour se reposer." ${ }^{55}$ The published survey, too, is credited only to Martel, Viré and Armand. So it seems that Hovey, as a distinguished not-so-young foreign visitor, was allowed to accompany the surveying party on the second and third days of their work, once the entrance shaft had been descended and the severity of the cave assessed. Hovey was 64 years old at the time, compared with Martel's age of ${ }^{38}$.

The presentation inscription (Fig. 4) in the copy of his book that Hovey gave to Martel was dated five weeks later, on October $26^{56}$. This may have marked his farewell, or it may have been posted from America when he returned home. The book ("Don de l'auteur") was reviewed by Martel ${ }^{52}$, and so also was the smaller book in which Call collaborated with Hovey ${ }^{44}$.

Hovey`s membership of the Société started in 1897 and he was still shown as a member in the last of the published membership lists, for 1 October $1909^{19}$. Martel noted that "M. Hovey nous a ... promis de nous fournir désormais un certain nombre de rapports précis sur l'état actuel des cavernes américaines et sur les travaux et découvertes dont elles ont été l'objet depuis quinze ans." ${ }^{52}$ Papers by him did indeed appear in Spelunca, in $1899^{13}, 190457$ and $1909^{58}$, in addition to the Mammoth Cave bibliography of 1914 , compiled jointly with Ellsworth Call. Two of these papers ${ }^{13,57}$, however, appear to be unacknowledged translations of ones already published in America $^{12,59}$ with only minor alterations to the text.

A lengthy review by Hovey of Martel’s small book La Spéléologie, ou science des cavernes, appeared in the American journal Science in $1900^{60}$. 
Hovey died while Martel's paper on Mammoth Cave was being printed and Martel added a personal footnote to it $^{61}$ :

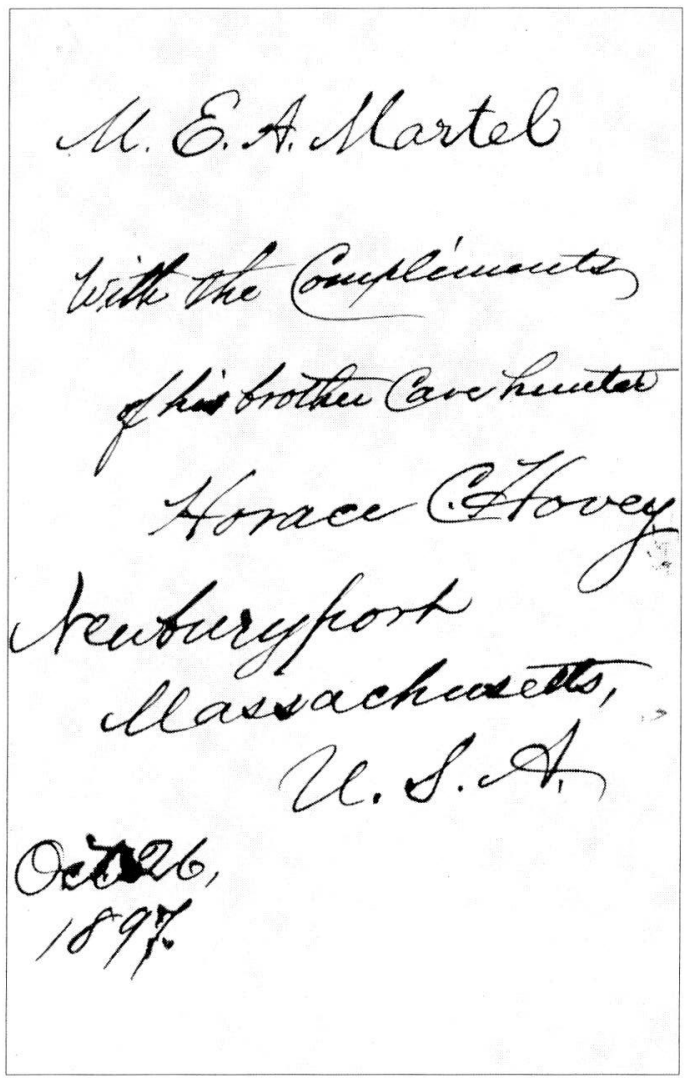

Fig. 4. Hovey's inscription in the copy of his book. Celebrated American Caverns, which he gave to Martel.

"Notre vénéré et regretté collègue est décédé le 27 juillet 1914, à Newbury - Port (Mass.), à l'âge de 81 ans; il a pu voir paraître son dernier travail. Sa longue et belle vie fut un modèle de labeur scientifique, de haut dévouement et d'inépuisable bonté."

\section{PERCY VAN EPPS}

One more American member of the Société remains to be noticed.Percy Myers Van Epps - erroneously written as "Percy (Van Epps)", i.e. Van Epps Percy, in the membership lists ${ }^{18.19}$ - joined the Société in 1898 and was still a member on 1 October 1909. He was an archaeologist, but his sole report in Spelunca ${ }^{62}$ is concerned with the influence of water and changes in land level on caves. A cave report he published in America was given a brief notice in Spelunca ${ }^{62 A}$. 


\section{MARTEL'S 1912 VISIT TO USA}

Martel`s first and only visit to USA took place in 1912. Already he had several friends and professional colleagues there (though Hovey was by then too old to accompany him), but the occasion of his 1912 visit was The Transcontinental Excursion in celebration of the $60^{\text {th }}$ anniversary of the American Geographical Society. Letters of invitation had been sent out in June 1911 to the leading geographical societies of Europe, asking each to nominate a certain number of participants. The excursion lasted 57 days, covered more than $21000 \mathrm{~km}$ and comprised 43 European geographers representing 14 countries, together with about 70 American geographers most of whom came and went at their convenience. The main organizer was W.M. Davis who, 18 years later, was to write his classic paper on speleogenesis.

Among the guests from Europe was "Edouard-Alfred Martel, late President, Commission Centrale de la Société de Géographie, Paris; Editor of La Nature; Collaborator, Geological Survey of France" ${ }^{\prime 3}$.

The visitors began to arrive in New York about 12 August 1912, and Martel is thought to have left France shortly after 10 August $^{64}$. Various meetings and more or less local excursions took place during the next week or so and then on 22 August the main Transcontinental Excursion began ${ }^{65}$. It lasted for eight weeks and included Niagara Falls and the Great Lakes, Chicago, North Dakota, the Yellowstone National Park, Seattle, Oregon, California, Nevada, Utah, the Grand Canyon, Kansas City, Memphis, Charlottesville and Washington ${ }^{66}$. Martel produced five non-karst papers as a result of these visits ${ }^{67}$, in addition to those on Mammoth Cave. The knowledge he gained of American National Parks was put to good use shortly afterwards when he was arguing the case for Parcs Nationaux in France ${ }^{67 \mathrm{~A}}$.

The archives of the American Geographical Society contain no additional information or correspondence about Martel's visit, though they do have a carte-de-visite photograph he had sent them ${ }^{68}$, taken by F. Fetzer of Switzerland in $1901^{69}$.

In order to visit Mammoth Cave, Martel had to leave the main party and proceed on his own. He was with the rest at the Roosevelt Dam in Arizona on 5 October; but on 10,11 and 12 October $^{70,71}$ he was at Mammoth Cave, while on the $13^{\text {th }}$ he was still in the area, taking altitude readings on the surface ${ }^{72}$. The official excursion passed through Kansas City on October 8 and Memphis on October 9, en route to Birmingham (Alabama) where they arrived on October $10^{66}$. Most probably Martel left the others at Memphis, whence a single train journey would take him to Nashville (Tennessee) or Bowling Green (Kentucky) for Mammoth Cave. He could then have rejoined the main party at Washington between 14 and 16 October or at New York on 17 October just before they disbanded.

He stayed at Mammoth Cave as a guest of the management ${ }^{70}$. Two photographs survive (Figs. 5 and 6), one of them showing him at the entrance of the nearby Salts Cave. According to Helen Randolph ${ }^{73}$, in whose book these photographs were published:

The famous French scientist said that Mammoth Cave was the last cavern he expected to visit - that he regarded his visit to Mammoth Cave as the culminating of his cave explorations and investigations. The hardships he had undergone in a lifetime, primarily devoted to cave explorations, were such, he declared, as to make it neces- 
sary for him thenceforth to conserve his physical energies, and his visit to the greatest known cavern in the world, he averred, afforded a fitting climax.
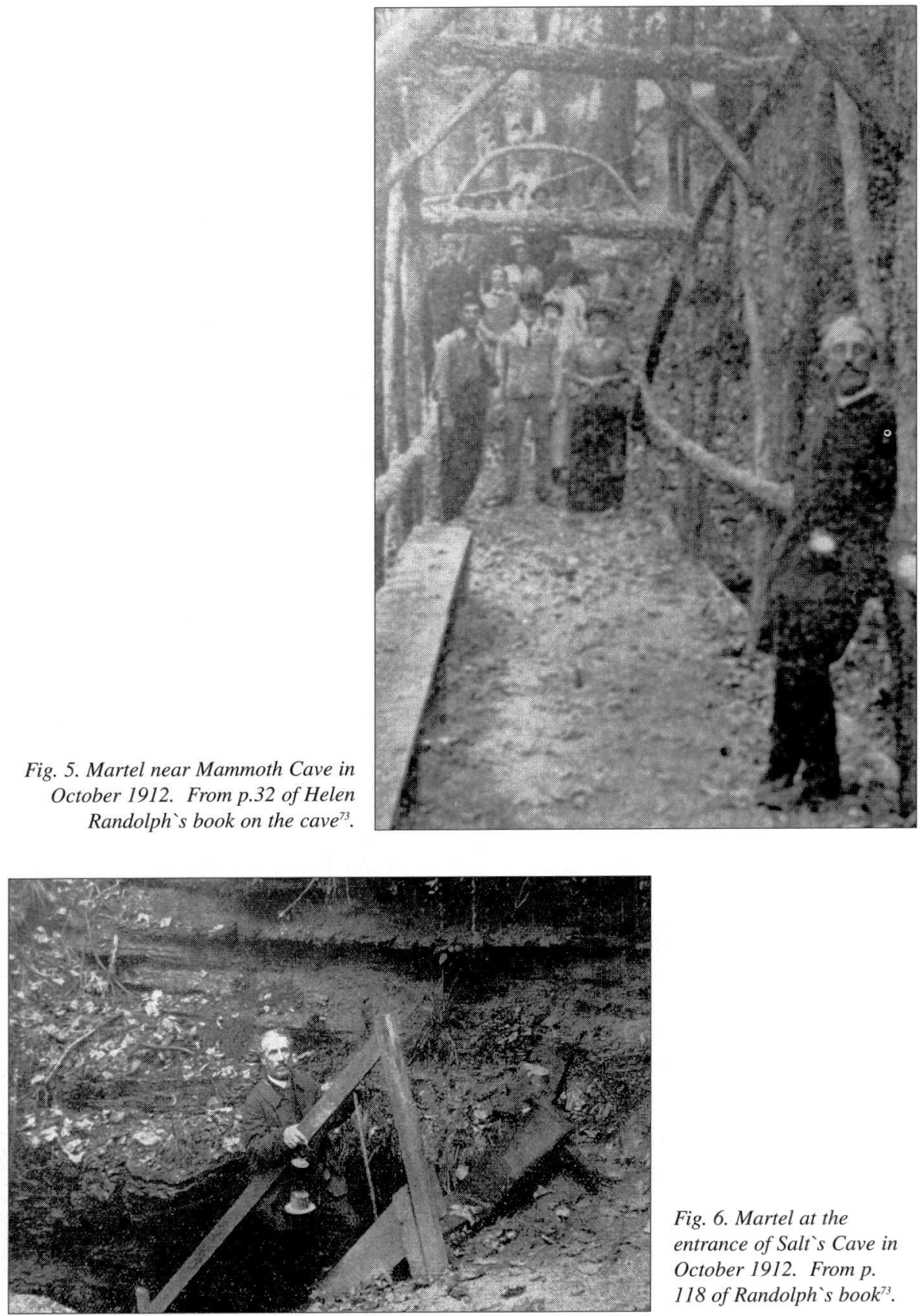

Fig. 6. Martel at the entrance of Salt's Cave in October 1912. From $p$. 118 of Randolph's book ${ }^{73}$. 


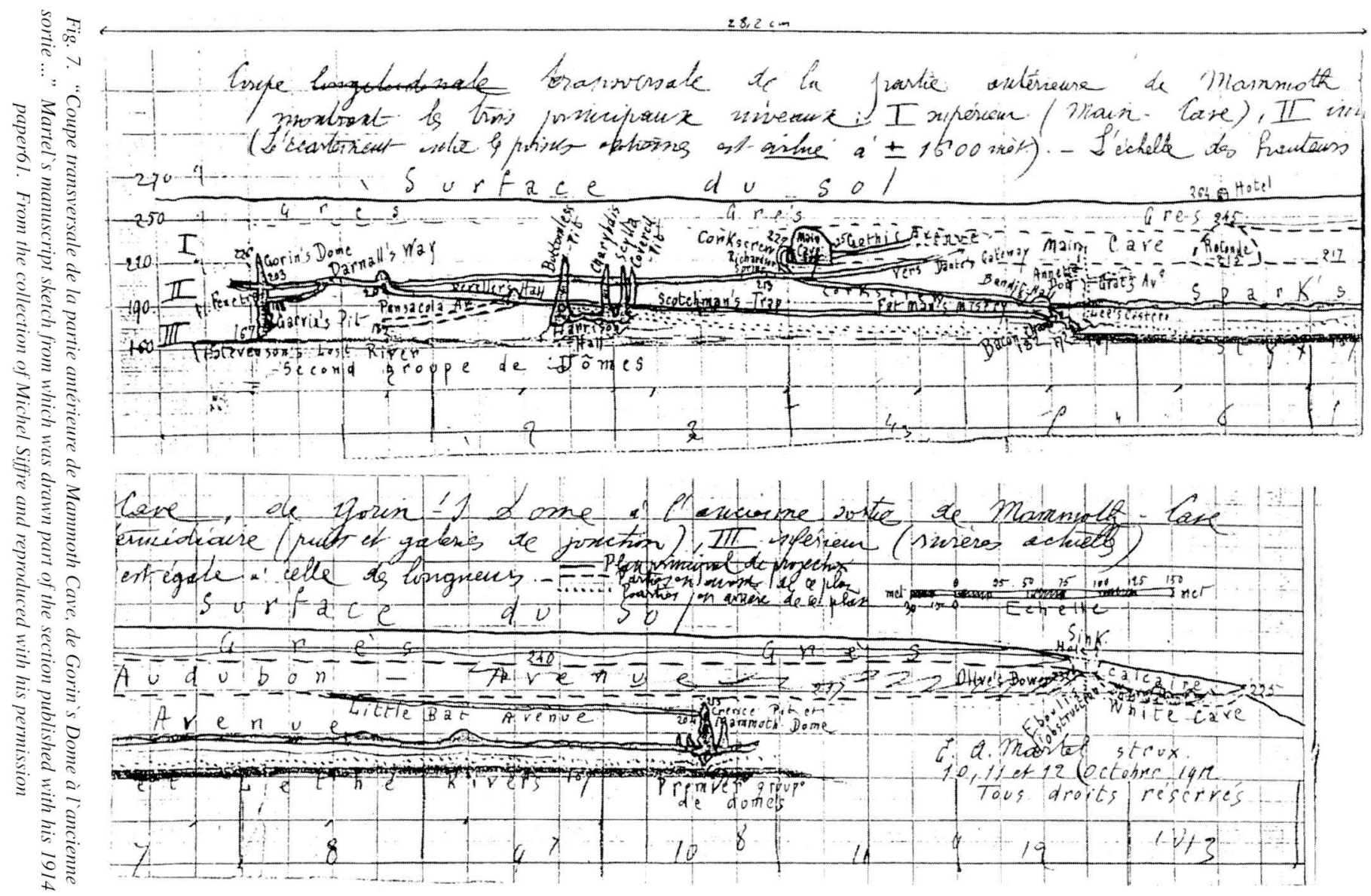


Martel himself described his visit to the cave, and the work he did there, both in a lecture to the Académie de Sciences in Paris ${ }^{74}$ and in a lengthy paper in Spelunca61. His manuscript sketch sections (Fig. 7) formed the basis for those published in the latter. Such a longitudinal section of Mammoth Cave was new, no such attempt having been made since Edmund Lee`s survey of 1835 . What was particularly significant was its using altitudes obtained from aneroid barometer readings.

He believed that this was the first time that such readings had been taken:

"Il m`a été permis d’effectuer pour la première fois des observations barométriques qui ont fixé les altitudes relatives des divers étages; ainsi j’ai pu construire un essai de coupe synthétique générale faisant connaître le réel dipositif de Mammoth Cave et expliquant sa formation. ${ }^{74}$ "

He had, however, been preceeded by J. F. Campbell of Scotland in $1864^{75,76}$. When Campbell used the aneroid barometer it had not been long in existence, having been invented in France in 1845. Campbell had only one day at the cave, 13 October 1864, so his observations were less extensive than Martel's. They were also less accurate but not ridiculously so. The altitudes obtained by Campbell and Martel, compared with those of modern surveyors are shown in Table 1.

One of the more remote passages in the cave was named the Martel Avenue but this was done before his 1912 visit. The name appeared first in Hovey`s "Nouvelle carte de Mammoth Cave" dated 1907 and published in Spelunca in $1909^{58}$ where he refers to "la longue et nouvelle Martel-Avenue, ainsi nommée en reconnaissance des éminents services rendus par cet explorateur de grottes." The name was used also in Kaemper's manuscript place of $1908^{77}$ and again in Hovey`s further revised plan in his 1909 guidebook $^{78}$.

\section{THE BIBLIOGRAPHY OF MAMMOTH CAVE, 1914}

Arguably the most important result of Martel's links with cave researchers in USA was the publication in 1914 of the bibliography of Mammoth Cave (Fig. 8) containing 425 entries $^{83}$. Significantly, this was compiled by Hovey and Ellsworth Call, Martel's contribution being to edit it and to translate the annotations into French. More importantly, it was because of Martel's interest, and the existence of the journal Spelunca that he had created 19 years earlier, that the bibliography was published at all. Jillson ${ }^{84}$, who produced the next substantial Mammoth Cave bibliography in 1953, wrote that

Hovey`s work, failing to find an American publisher, was translated by E. A. Martel into the French and issued in Paris. ... Few copies found their way to the West, and though it deserved a better fate, its effect and importance on Mammoth Cave writing and research has been negligible.

Not only was the Hovey/Call/Martel bibliography the first by many years and the only one widely available throughout the world, even today, but it also contained references that were not incorporated in the later bibliographies of Jillson ${ }^{84}$ and of Wilkes $^{85}$. These references were mostly those covering the fauna of the cave but some straightforward descriptive items were also omitted. 


\section{SPELLUNCA}

BULLETIN ET MEMOIRES

DB LA

SOCIETE IIE SPELEOLOGIE

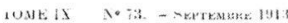

\section{BIBL OGRAPHIE}

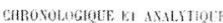

MAMMOTU CAVE. KENTEKY

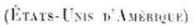

$$
\text { PSR }
$$

HORACE LARTEB HOVEY $\mathrm{W}$ RICHARD ELLSWORTH CALL

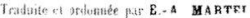

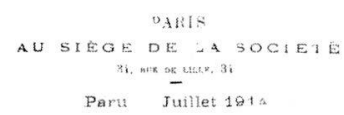

Fig.8 The title page of the Mammoth Cave bibliografy compiled by Hovey and Call and published in France in $1914^{83}$.

\section{CONCLUSION}

Although Martel`s stimulation and encouragement of his American friends resulted in the activity already described, and especially in the publication of American papers in an international specialist journal, his influence in USA did not last. He did not himself propose the formation of a cave society there, as he had in some parts of Europe $^{1}$, but Hovey, perhaps influenced by the success of the Société de Spéléologie, had in 1896 urged the creation of "an American Cavern Club" ".6 . The time was evidently not yet ripe for this, one factor probably being the vast distances separating those few people in America who were interested in caves.

In the early 1930s it was still too early for such a society to be formed, for the American naturalist Thomas Barbour wrote ${ }^{87}$, of that period:

I became so interested in caves at one time that I suggested to Professor William Morton Wheeler that we start a Society of Speleologists. He was enthusiastic, but we finally concluded that there was not enough of an interested group to make it worth trying. 
The National Speleological Society`s forerunner, the Speleological Society of the District of Columbia, was finally created in 1939. As a distinguished present-day American speleologist wrote recently ${ }^{88}$ :

It is a shame that Martel was not around in the 1940s to visit with Bill Stephenson and help get the National Speleological Society started - we could have used Martel's guidance.

\section{Acknowledgements}

I am particularly grateful to Michel Siffre for allowing me to reproduce, from his collection, an original Martel sketch of part of the longitudinal section he drew of Mammoth Cave.

Daniel André first made me aware of that sketch and also provided information since published in La Plume et les Gouffres. Gordon Smith sent me a copy of Randolph`s Mammoth Cave book of 1924, containing the photographs of Martel in Kentucky; Dr. William Halliday discussed many things including the location of the Hovey papers; and Ray Mansfield gave me the benefit of his wide knowledge of Mammoth Cave literature.

\section{Editorial note}

This paper is an English translation of the one presented by tha author on 18 October 1997 at the Colloque E.A. Martel in Mende (Lozère, France). It is printed with the permission of the organizers of that Colloquium.

\begin{tabular}{|l|c|c|c|}
\hline & \multicolumn{3}{|c|}{ Depth in metres below cave mouth } \\
\hline \multicolumn{1}{|c|}{ PLACE } & $\begin{array}{c}\text { Campbell } \\
1864\end{array}$ & $\begin{array}{c}\text { Martell } \\
1912\end{array}$ & $\begin{array}{c}\text { Miotke } \\
\text { Pamer }^{79} \\
\text { White et al. }\end{array}$ \\
White \& White & \\
\hline Hotel & 27.4 above & 31.1 above & 30.5 above \\
\hline Cave Mouth & 0 & 0 & 0 \\
\hline Arm Chair & 8.2 & 7.0 & - \\
\hline Richardson's Spring & 32.9 & 14.0 & - \\
\hline $\begin{array}{l}\text { Great Relief } \\
\text { Bacon Chamber }\end{array}$ & 65.9 & 50.9 & 49.4 \\
\hline Lethe River & 84.8 & 65.9 & 54.9 \\
\hline Green River & 75.3 & 68.9 & 66.8 \\
\hline
\end{tabular}

Table I - Mammoth Cave depth figures obtained by Campbell in 1864, Martel in 1912 and by modern surveyors. 


\section{NOTES AND REFERENCES}

1. Shaw, T.R. 1994. The wider purpose of Martel`s visits abroad. Acta Carsologica, 23:221-231.

2. Mais, K. 1994. Kraus und Martel - eine verbinende Achse in Sache Karst. ActaCarsologica 23:191204

3. Martel, E.A. 1894. Les abimes... Paris, Delagrave,viii, 578, [ii]pp. (pp.547-548).

4. Lynch, W.H. 1897. Marble - Cave (Missouri). Spelunca - Bull de la Société de Spéléologie 3 (12):204206

5. Le Couppey de la Forest, M. 1904. Quelques grottes des États - Unis d'Amérique.Spelunca - Bull. et Mém. de la Société de Spéléologie. 5 (35) for Nov. 1903:115-135

6. George, A.I. 1990. Le Couppey de la Forset and the maps of Mammoth Cave and Wyandotte Cave. Journal of Spelean History 24 (4):7-8

7. Martel, E.A. 1905-06. La Spéléologie au xxe siècle. Spelunca - Bull. et Mém. de la Société de Spéléologie 6 (41-46) : 1-810 (6(42) 1906 : 416 - 433)

8. Martel, E.A. 1910. L`hydrologie souterraine aux États-Unis. Spelunca - Bull. et Mém de la Société de Spéléologie 8 (59):[3]-34

9. Martel, E.A. 1893. The land of the Causses. Appalachia: 7(1):[18]-30: 7(2):[130]-149

9A. Martel, E.A. 1906. Into the earth`s depths twenty years of cave-exploring. Sunday Magazine for 28 January : 9-10, 16

10. Martel, E.A. 1904. Scientific exploration of caves. Report of the eighth International Geographic Congress at Washington D.C. 1904 : 165-172 (pp. 166-171)

11. R[itchie], J. 1896. [Review of] Spelunca : Bulletin de la Société de Spéléologie Appalachia 8(1) : 7273

12. Hovey, H.C. 1899. Mapping the Mammoth Cave. Scientific American Supplement 48(1229) July 22 : 19707-19708

13. Hovey, H.C. 1899. Cartographie de la caverne Mammoth. Spelunca - Bull. de la Société de Spéléologie 5 (17-20) Dec. : 8-15

14. Anon. 1904. Sociétés et revues correspondantes. Spelunca -Bull. et Mém. de la Société de Spéléologie 5 (37):[202]-205.

15. Anon. 1909. Sociétés et revues correspondantes. Spelunca - Bull. et Mém. de la Société de Spéléologie 7 (57):[313]-316

15A. e.g. Bull. American Geographical Society 29(1)1897:95-96 and 42(4)1910:292-294; also Appalachia 8(3)1897:251-252

16. Not to be confused with Herbert Ernest Balch (1869-1958), an English cave explorer and archaeologist who worked in the Mendip Hills of Somerset.

17. Anon. 1895. Liste des membres au 1er mai 1895. Spelunca - Bull. de la Société de Spéléologie 1:[15]19

18. Anon. 1904. Liste des membres au 1er septembre 1904. Spelunca - Bull. et Mém. de la Société de Spéléologie 5(37):[193]-200

19. Anon. 1909. Liste des membres au 1re octobre 1909. Spelunca-Bull. et Mém de la Société de Spéléologie 7(57):[305]-311.

20. Halliday, W. R. 1970. Introduction. pp. v-xxxiii in E.S. Balch. 1970. Glacières or freezing caverns. New York, Johnson Reprint Corporation. xxxiii, [xi], 337pp. 
21. Halliday, W. R. 1979. Edwin Swift Balch - almost an American Martel. Journal of Spelean History $13(1-2): 38-40$

22. Balch, E.S. 1900. Glacières or freezing caverns. Philadelphia, Allen, Lane \& Scott. [xi], 337 pp.

23. It was recently reintroduced to the karstologists of Central Europe by Glazek. J. 1995. E.S. Balch (1856-1927) - American investigator of ice caves - in Slovakia a century ago. Caves and man. Proceedings International Symposium on the occasion of the 70th anniversary [of] opening to the public of the Demänovská cave of Liberty. 4-8 October 1994 Demänovská dolina ... Liptovsky Mikulá_. pp. 4751 .

24. Martel, E.A. 1997. La plume et les gouffres Correspondence d`Edouard-Alfred Martel (de 18681936)... Lozère, Association E.-A. Martel. 607pp. (pp. 117-118). The letter is undated but not earlier than June 1892.

25. Balch, 1900. Op. cit., p. [vii].

26. Balch. 1900. Op. cit., pp. 205-208, 214-215, 221-222, 300-301.

27. Spelunca - Bull. de la Société de Spéléologie 6(23-24) 1900:153-154.

28. Spelunca - Mém. de la Société de Spéléologie 1(11) 1897:349-353.

29. Owen, L.A. 1898. Cave regions of the Ozarks and Black Hills. Cincinnati, Editor Publishing Co. [v], $228 \mathrm{pp}$.

30. Eberle, J.F. 1977. The incredible Owen girls. St. Louis, Missouri, Boar`s Head Press. [vii], 181, [v] pp. (pp.80-81).

31. Vineyard, J.D. 1970. Introduction. Pp. v-xlii in L.A. Owen. 1970. Cave regions of the Ozarks and Black Hills. New York, Johnson Reprint Corporation. xlii, [xvii], 228 pp.

32. Bull. American Geographical Society 30 (4) 1898:368.

33. Anon. 1895. Comptes rendus d`ouvrages offerts. Spelunca - Bull. Société de Spéléologie 1 (4):139.

34. Owen, L.A. 1896. Cavernes américaines. Spelunca - Bull. de la Société de Spéléologie 2 (5) : 8-13.

35. Owen, L.A. 1897. Marble Cave (Missouri) et Wind Cave (Dakota). Spelunca - Bull. de la Société de Spéléologie 3 (9-10) : 22-31,87.

36. Owen, L. A. 1898. La caverne de Cristal. Spelunca - Bull. de la Société de Spéléologie 4 (14):7781.

37. Owen, L.A. 1899. Les cavernes de Ha Ha Tonka. Spelunca - Bull. de la Société de Spéléologie 5(1720):16-20.

38. Spelunca - Bull. de la Société de Spéléologie 4(16) 1898 : [199]-[201].

39. Meloy, H. [R]. 1978. Dr. Call at Mammoth Cave. Journal of Spelean History 11(3):42-45.

40.Cleevely, R.J. 1983. World palaeontological collections. London, British Musium (Natural History) 365pp.

41. Hovey, H.C. and Call, R.E. 1897. Mammoth Cave of Kentucky an illustrated manual. Louisville, J.P. Morton [ii].v, i, 107, [ii] pp. Reprinted in 1899 and 1906. In the revised 2nd endition of 1912, Mammoth Cave of Kentucky with an account of Colossal Cavern (v, $131 \mathrm{pp})$, Call is no longer named as joint author on the title page, though the sections of text he wrote remain.

42. Call, R.E. 1897. The evolution of the maps of Mammoth Cave (Kentucky). Proc. Indiana Academy of Science for $1896: 46-52$.

43. Call, R.E. 1897. La cartographie de Mammoth Cave (Kentucky). Spelunca - Bull. de la Société de Spéléologie 3(9-10) : 12-22. 
44. Mém. de la Société de Spéléologie 1 (11) 1897 : 408, 410-411.

45. Mém. de la Société de Spéléologie 1 (11) 1897 : 354.

46. Halliday, W.R. 1970. Introduction. Pp. v-xxxviii in H. C. Hovey. 1970. Celebrated American caverns ... New York, Johnson Reprint Corporation xxxviii, xii,228pp.

47. Halliday, W.R. 1972. First in American caves. The life and spelunking of the Reverend Horace C. Hovey. Journal of Spelean History 5(1): 7-10.

48. Anon. 1995. Horace C. Hovey. Journal of Spelean History 29(4):89-95.

49. Hovey, H.C. 1882. Celebrated American caverns, especially Mammoth, Wyandot, and Luray. Together with historical, scientific, and descriptive notices of caves and grottoes in other lands. Cincinnati, Robert Clarke, xii, 228pp. One copy of this 1882 edition (belonging to the Karst Research Insitute in Postojna) is known with an additional publishers imprint pasted on the title page, "London Crosby Lockwood and Co. 7, Stationers` Hall Court, Ludgate Hill", indicating joint publication with an associate in England.

50. Halliday, W.R. 1980. Horace Carter Hovey - an unfinished story. Journal of Spelean History 14 (1) : 10-12. Halliday believes that in addition to the Hovey family papers in the Wabash College Library (Crawfordsville) in which there are big gaps, other papers may be with those of his son Edmund Otis Hovey in the American Museum of Natural History; he was unable to gain access to these.

51. Halliday, W.R. 1995. Unpublished letter dated 5 November, addressed to T.R. Shaw. A living member of the Hovey family is said to have some H.C. Hovey papers but will not let them be examined.

52. [Martel, E.A.] 1897. [Review of] H.C. Hovey, Celebrated American Caverns... Spelunca - Bull. de la Société de Spéléologie 3(12) : 216 52A. Information from Congress publications via Wendy Cawthorne of the Geological Society Library in
London.

53. Anon. 1898. The American Association [for the Advancement of Science]. Fiftieth anniversary. Bull. American Geographical Society 30 (4) : 305-312 (p.309).

54. Hovey, H.C. 1898. The Aven Armand, Lozere, France. Scientific American 78(15):228-229 (p.228). Other caves in the Causses visited by Hovey`s party included Baumes Chaudes, Dargilan and Bramabiau (Hovey, H.C. 1898. The region of the Causses in Southern France. Proceedings of the American Association for the Advancement of Science 47th meeting: 294 - 295).

55. Martel, E.A. 1899. 10e campagne souterraine (1897) Seconde partie Dans les Causses (Aven Armand, Grottes de Ganges, Gouffres de Sauve, etc.). Mém. de la Société de Spéléologie 3(20): 255-288 (pp.260[263]).

56. Hovey, H.C. 1896. Celebrated American caverns ... [2nd edn.] Cincinnati, Robert Clarke. This edition differs from the one of 1882 only by the additon of 6 new pages ( $p$ p 122a-122e, plus a plan). The copy inscribed by Hovey is in the library of the Karst Research Institute at Postojna.

57. Hovey, H.C. 1904. Colossal Cavern (Kentucky). Spelunca - Bull. et Mém. de la Société de Spéléologie 5(37): 247-[251].

58. Hovey, H.C. 1909. La nouvelle carte de Mammoth - Cave. Spelunca - Bull. et Mém. de la Société de Spéléologie 7(57):361-364.

59. Hovey, H.C. 1903. The Colossal Cavern of Kentucky. Scientific American Supplement. 56(1455) Nov. $21: 23316$ - 23319.

60. Hovey, H.C. 1900. [Review of] La spéléologie, ou science des cavernes. Par E.A. Martel. Science, New York, new series 12 (303):608-610.

61. Martel, E.A. 1914. Explication sur Mammoth Cave 1912. Spelunca - Bull. et Mém. de la Société de Spéléologie 9 (74) for Dec. 1913: [239]-302 (the footnote is on p.[241]).

62. Van Epps, P. 1899. Notes de spéléologie américaine. Spelunca - Bull. de la Société de Spéléologie 5(17-20):20-23. 
62A. Anon. 1898. Spelunca - Bull. de la Société de Spéléologie 4(13):49.

63. Anon. 1915. Memorial volume of the transcontinental excursion of 1912 of the American Geographical Society of New York. New York, Am. Geog. Soc., xi, 407pp (p.33).

64. Martel, E.A. 1997 Op. cit. pp. 248, 586.

65. Anon. 1912. The Society`s transcontinental excursion. Bull. American Geographical Society 44(9):664-668.

66. Anon. 1915. Op. cit. pp. 44-45.

67. Four of these are listed under the years $1912-1914$ by C. Chabert and M.C. de Courval. 1971. E.A. Martel 1859-1938 bibliographie. [Travaux Scientifiques du Spéléo-Club de Paris]. In addition he wrote Les ferry-boats de l'Hudson-River à New York. La Nature (2111). Nov. 8, 1913 (Anon. 1915. Op. cit. p.22).

67A. Martel, E.A. 1913. La question des parcs nationaux en France. La Montagne (7), juillet : 401-412 \& (8), août : 433-457.

68. American Geographical Society. 1996. Unpublished letter dated 21 June, addressed to T.R. Shaw.

69. The same photograph is reproduced and dated on p.824 of E.A. Martel 1921. Nouveau traité des eaux souterraines. Paris, Doin. It also appears, greatly enlarged, on p.[185] of Martel. 1997. Op. cit.

70. Martel, E.A. 1997. Op. cit. pp.586-587.

71. Martel, E.A. 1914. Op. cit., survey opp. p.302.

72. Martel, E.A. 1914. Op. cit., p.278.

73. Randolph, H.F. 1924. Mammoth Cave and the cave region of Kentucky. Louisville, Standard Printing Co. 153 , iii pp. (pp[32],33, 39, [118], 121).

74. Martel, E.A. 1914. Sur Mammoth Cave (Kentucky...). Comptes Rendus de l'Académie des Sciences 159:1013-1016.

75. [Campbell, J.F.] 1865. A short American tramp in the fall of 1864. Edinburgh, Edmonston and Douglas. vii, 427pp. (Pp.344-351).

76. Shaw, T.R. 1991. Barometric depth measurements in Mammoth Cave. Journal of Spelean History 25(3):33-44.

77. Kaemper, M. 1981. Map of the Mammoth Cave Kentucky 1908. [Coloured reproduction] redrafted by D.O. Daunt. Cave Research Foundation. Single sheet.

78. Hovey, H.C. 1909. Hand-book of the Mammoth Cave of Kentucky a practical guide to the regulation routes. Louisville, J.P. Morton. 63pp. (p.[2]).

79. Miotke, F.D. [1975]. Die Höhlen im Mammoth Cave- Gebeit (Kentucky). Wurzburg, Böhler. vii,133pp.

80. Palmer, A.N. 1981. A geological guide to Mammoth Cave National Park. Teaneck, Zephyrus Press. xiv, 196pp.

81. White, W.B., Watson, R.A., Pohl, E.R., and Brucker, R. 1970. The central Kentucky Karst. Geographical Review 60(1):88-115.

82. White, W.B. and White, E.L. (eds.) 1989. Karst hydrology concepts from the Mammoth Cave area. New York, Van Nostrand Reinhold. xiii, 346 pp.

83. Hovey, H.C. and Call, R.E. 1914. Bibliographie chronologique et analytique de Mammoth Cave, Kentucky (États - Unis d`Amérique) 1815 à 1914. Spelunca - Bull. et Mém. de la Société de Spéléologie 9(73) for Sept. 1913:191-237.

84. Jillson, W.R. 1953. A bibliography of Mammoth Cave (1798-1949). Frankfort, Roberts Printing Co. 81 pp. (p.[6]), 
85. Wilkes, F.G. 1962. Bibliography of Mammoth Cave National Park, Mammoth Cave, Kentucky. University of Louisville [i], 63pp.

86. Hovey, H.C. 1896. The Colossal Cavern of Kentucky. Scientific American 75 (9):183.

87. Barbour, T. 1943. The sea and the cave ... Atlantic monthly 171(4) : 99-103 (p.101).

88. Smith, G.L. 1995. Unpublished letter dated December 11, addressed to T.R. Shaw. 